\title{
CERVICAL ENDOSCOPIC DISC SURGERY: PRECISE APPROACH FOR MINIMALLY INVASIVE DECOMPRESSION
}

\author{
CIRURGIA DO DISCO ENDOSCÓPICO CERVICAL: ABORDAGEM PRECISA PARA \\ DESCOMPRESSÃO MINIMAMENTE INVASIVA
}

\author{
CIRUGÍA DE DISCO CERVICAL ENDOSCÓPICA: ENFOQUE PRECISO PARA LA \\ DESCOMPRESIÓN MIINIMAMENTE INVASIVA
}

Artem Gushcha ${ }^{1}$, Sergey Arestov ${ }^{1}$, Andrey Vershinin ${ }^{1}$, Alexey Kashcheev ${ }^{1}$, Vladimir Tuurnikov ${ }^{1}$, Maksim Dreval ${ }^{1}$, Ekateryna Poltoraco ${ }^{1}$, David Petrosyan ${ }^{1}$

1. Research Center of Neurology, Moscow, Russia.

\begin{abstract}
Objective: Technological advances in recent decades have led to a complexity of choice of the most effective method for treating cervical disc herniations. The idea of removing disc herniations using endoscope techniques is not new, and is successfully used in the treatment of lumbar disc herniations. But in the case of the cervical spine, full endoscopic procedures only started to be performed at the beginning of 2014, by Yang JS and coauthors, and their effectiveness was and still is a matter of controversy. The proposed method of endoscopic portal disc herniation removal was used for the past two years, and its results were compared with the anterior microsurgical approach using a single-level cage implantation. Methods: Twenty-five patients were included in this study, with a comparator group of 25 patients operated by ordinary anterior cervical discectomy with a single-disc fusion. All patients were operated on by the same group of surgeons. Results: During the analysis of VAS data, it was confirmed that the degree of local and radicular pain in the two groups was not significantly different $(p>0.05)$. According to the Neck Disability Index (NDI) there was a significant difference between the two groups in relation to the endoscopic patient group. Data using the Odom criteria showed significantly better results for the endoscopic group. During the research it was observed that the patients in the endoscopically operated group were discharged from hospital more quickly, after 3 [2; 5$]$ days compared to $5[4 ; 6]$ days in the microsurgery group. Conclusion: The method performed is a safe and reliable alternative to convenient surgical techniques. Level of Evidenced II; Therapeutic study, investigating the results of treatment.
\end{abstract}

Keywords: Humans; Intervertebral disc displacement; Diskectomy; Endoscopy; Cervical vertebrae; Neuroendoscopy.

\section{RESUMO}

Objetivo: Os avanços tecnológicos das últimas décadas determinaram a complexidade da escolha do método mais eficaz para o tratamento das hérnias discais cervicais. A idéia de remover hérnias de disco usando técnicas de endoscópios não é nova e é utilizada com sucesso no tratamento de hérnias discais lombares. Mas, no caso da coluna cervical, apenas procedimentos totalmente endoscópicos são realizados a partir de 2014 por Yang JS com coautores e sua eficácia foi e ainda é um assunto questionável. O método proposto de remoção da hérnia discal portal endoscópica foi utilizado durante os últimos 2 anos e seus resultados foram comparados com a abordagem microcirúrgica anterior utilizando um implante em gaiola de nível único. Método: 25 pacientes foram incluídos neste estudo, com um grupo comparativo de 25 pacientes operados por discectomia cenvical anterior comum com uma fusão de disco único. Todos os pacientes foram operados com o mesmo grupo de cirurgiões. Resultados: Durante a análise dos dados da EAV confirmou-se que o grau de dor local e radicular nos dois grupos não foi significativamente diferente $(p>0,05)$. De acordo com o Neck Disability Index (NDI), houve uma diferença significativa entre dois grupos em relação ao grupo de pacientes endoscópicos. Dados usando critérios de Odom mostraram resultados significativamente melhores no grupo endoscópico. Durante a pesquisa, percebeu-se que os pacientes do grupo operado endoscopicamente tiveram alta mais rápida do hospital em 3 [2; 5] comparado com 5 [4; 6] dias no grupo microcirúrgico. Conclusão: 0 método realizado é uma alternativa segura e confiável para técnicas cirúrgicas convenientes. Nível de Evidência II; Estudos terapêuticos - Investigação dos resultados do tratamento.

Descritores: Seres humanos; Des/ocamento do disco intervertebral; Disotomia; Endoscopia; Vértebras cervicais; Neuroendoscopía.

\section{RESUMEN}

Objetivo: Los avances tecnológicos durante las últimas décadas han llevado a una elección compleja sobre el método más efectivo para el tratamiento de hernias de disco cervical. La idea de eliminar las hernias discales usando técnicas endoscópicas no es nueva y se utiliza con éxito en el tratamiento de las hernias de disco lumbar. Pero en el caso de la columna cervical, procedimientos totalmente endoscópicos solamente empezaran a ser realizados en el inicio de 2014, por Yang JS y coautores, y su efectividad era y sigue siendo un tema cuestionable. El método propuesto de remoción de la hernia discal endoscópica se utilizó durante los últimos 2 años y sus resultados se compararon con el enfoque microquirúrgico anterior utilizando una implantación de caja en un solo nivel. Métodos: Se incluyeron 25 pacientes en este estudio con un grupo comparativo de 25 pacientes operados por discectomía cervical anterior común con una fusión de disco único. Todos los pacientes fueron operados con el mismo grupo de cirujanos. Resultados: Durante el análisis de los datos de EVA, se 
confirmó que el grado de dolor local y radicular en los dos grupos no fue significativamente diferente $(p>0,05)$. De acuerdo con el Índice de Discapacidad Cervical (NDI), hubo una diferencia significativa entre los dos grupos con respecto al grupo de pacientes endoscópicos. Los datos que utilizan los criterios de Odom mostraron resultados significativamente mejores en el grupo endoscópico. Durante la investigación, se observó que los pacientes del grupo que fuera operado endoscópicamente fueron dados de alta más rápidamente del hospital, en 3 [2; 5] días comparado con 5 [4; 6] días en el grupo microquirúrgico. Conclusión: El método realizado es una alternativa segura y confiable a las técnicas quirúrgicas convenientes. Niveles de Evidencia II; Estudios terapéuticos - Investigación de los resultados del tratamiento.

Descriptores: Seres humanos; Desplazamiento del disco intervertebral; Discectomía; Endoscopía; Vértebras cervicales; Neuroendoscopía.

\section{INTRODUCTION}

The prevalence of discogenic compression syndromes at the cervical level is extremely high nowadays. Despite the relatively small proportion of cervical disc intervertebral lesions detected among the total number of degenerative spinal lesions, according to J.S. Lawrence, ${ }^{1}$ around about $10 \%$ of the population experience periodic compression pain in the cervical spine or in the arm.

When assessing cervical disc herniation, a generally accepted classification of the staging of the formation of herniated intervertebral discs (protrusion, prolapse and sequestration) is that proposed by A.P. Decoul $x^{2}$, which is important in assessing the clinical course of the process and selecting the best form of treatment, as well as for classifying herniated intervertebral discs by their axial localization and relationship to the bone structures of the spinal canal. According to this, the median paramedian (laterally offset from the sagittal plane), lateral and foraminal hernias are distinguished.

Based on their analysis of a large number of clinical observations, J.H. Vland et al. ${ }^{3}$ distinguish the characteristic clinical signs that accompany the course of radicular compression at the cervical level. These signs are of practical importance for determining the level of lesion and axial localization of the herniation. Along with the characteristic radicular incidence of the pain syndrome, sensitivity disorders, prolapse of the tendon reflexes corresponding to innervated dermatome, as well as paresthesia, indicating lateralization of the compressed root in the foraminal opening, are often detected. In cases where the data are unclear, the use of the Spurling test is recommended ${ }^{4}$ (axial load on the neck with shaking from side to side).

$\mathrm{J}$. Knightly conventionally identifies two pathoanatomical variants of the formation of the compression substrate at the level of the intervertebral disc - soft disc (fragments of the fallen or prolapsing disc as an acute phase of the disease) and hard disc - the "hard disc" (appearance of osteophytes and their enlargement as a chronic phase of the disease). ${ }^{5}$ The structural state of the compressing factor, like its axial position, is the key, in our opinion, to the choice of surgical treatment tactics. In terms of clinical symptoms, patients with "soft disc" present predominantly brachialgia symptoms, often occurring after physical exertion, sudden head movement or neck trauma. The pain is acute radicular, spreading to the dermatomes, and often dependant on the position of the head and limbs.
The spread of pain like a "helmet" or a homolateral half of the head, like a hemicranium, is very characteristic in these patients. Hypesthesia accompanying this kind of compression always extends to single dermatomes and may be accompanied by an isolated decrease in tendon reflexes from adjacent muscles. A more rare violation is a reduction in strength (paresis) in the proximal parts of the upper limbs, often of a one-sided and unstable nature.

The symptomatology that accompanies the development of "hard disc" is characterized by headaches and pains in the hands, usually symmetrical and symptoms usually characterized as headaches and pain in arms. These symptoms are mostly symmetrical and accompanied by localized unstable pain during palpation at the level of herniation having some diagnostic value.. In such a course of the disease, multiple areas of decreased sensitivity are characteristic, and may include conductive anesthesia from the level of the lesion, with decreased muscle strength below the affected segment, involving deep paresis in more severe cases. The peculiarity of the clinical symptom in patients with ossified compression formations in the vertebral canal of the cervical level is the presence of normo- or hyperreflexia, which is considered a probable consequence of chronic circulatory disturbance at the base of the anterior spinal artery.

Clinical symptoms in patients with "hard disc" progress much more slowly than those in "soft" hernias.

Traditional CT and MRI studies provide complementary information for the diagnosis of pathology. The first is preferred for detecting compression factors (hernia, osteophytes), while the second is used to detect the effects of the compression (compression of the spinal cord and roots). Bischoff (2003) investigated the sensitivity, specificity and accuracy of CT, MRI and myelography in determining the diagnosis of "herniated disc" and "stenosis of the spinal canal." The accuracy and sensitivity of CT was slightly higher than that of MRI. CT remains the best method for assessing central stenosis. $\mathrm{MRI}$ provides an image of the entire cervical spine and enables the identification of stenosis in the direct sagittal projection. (Figure 1)

Studies by Jan T. Wilmink ${ }^{6}$ revealed the following clinico-radiographic correlations in CT.

1. Complete occlusion of the radicular opening by laterally migrated masses of the degenerated intervertebral disc ("soft disc") is always accompanied by radicular syndrome.
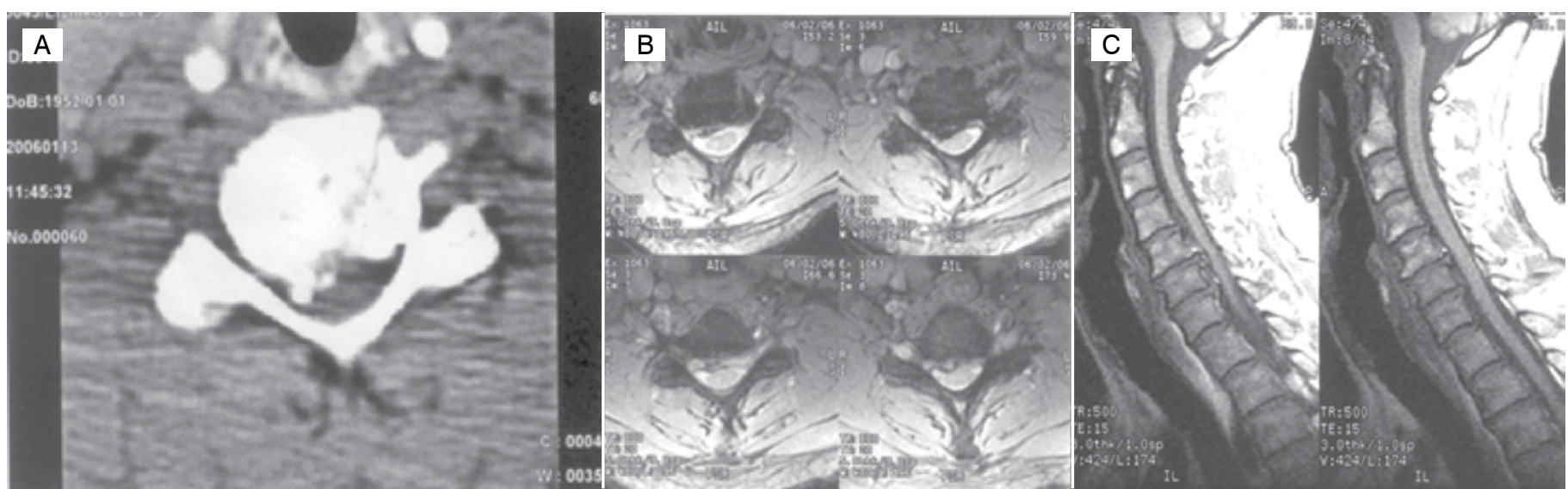

Figure 1. Diagnostic findings in patient with "soft" C6-C7 disc herniation. CT scans (A) accompanied with MRI (B, C) revealed characteristics of this lesion. 
2. Narrowing of the intervertebral opening with an osteophyte ("hard disc") causes edema of the root and a less pronounced radicular syndrome in comparison with the first variant.

3. Paramedian protrusions of the disc, which do not cause complete occlusion of the radicular opening and express compression of the spinal cord, often leading to the development of radicular symptoms on the contralateral side to the hernia.

The treatment of compression syndromes caused by degenerative changes in the cervical spine has a fifty-year history, but despite this, there is still no single criterion for choosing the best surgical intervention. On one hand, this is understandable due to the continuous improvement of surgical interventions at the cervical level and the development of operations "design" the spine. On the other, notions of the pathogenesis and biomechanics of change have deepened. Over the past fifty years, both anterior and posterior accesses to spinal surgery have developed in parallel. The development of the anterior access through the interfascial spaces was carried out by a transverse or oblique incision along the anterior edge of the nipple muscle by many surgeons. ${ }^{7,8}$ The history of posterior access begins in 1955, when D. Northfield proposed enlarged bilateral laminectomy one segment above and below the pathological level. ${ }^{9} \mathrm{~W}$. Scoville, in 1961, performed a limited bilateral laminectomy, supplemented by bilateral facet resection. ${ }^{10}$ In the development of the posterior approaches, the goal was to decompress neural formations by removing the posterior support back arch of vertebrae and the spinous process. Of these accesses, it was not always possible to remove the compression formations located on the ventral surface of the spinal canal, although there were isolated reports of the removal of disc hernia and osteophytes of the vertebral bodies. ${ }^{11}$ The posterolateral access includes posterior foraminotomy or facetectomy. This surgical technique was developed in 1944 by Spurling, ${ }^{4}$ and later, in more detail, by Frykholm, Scoville ${ }^{12}$ (keyhole technology). This kind of posterior access allowed a small incision to be made, to produce a foraminotomy and remove the disc hernia. However, due to the likelihood of neurological deficits and the need for segment stabilization, most neurosurgeons still prefer to use the safer anterior access. ${ }^{13}$ Existing endoscopic methods involve intra-disc interventions that do not allow for significant decompression of the spinal canal structures in the required volume.

In our department, for the last ten years, portal endoscopic discectomy has been widely used to treat hernias of the intervertebral discs of the lumbar spine, the effectiveness and safety of which has been proven. ${ }^{14}$ Since 2014 , this technology has been successfully used to treat herniated intervertebral discs of the cervical spine. Based on our experience, a detailed description of the operation of portal endoscopic discectomy of herniated intervertebral discs of the cervical spine, and the most significant technical features of this method, are presented in this paper.

It should be noted that the application of the method for operations at the cervical level is described for the first time in detail in both the domestic and foreign literature. Analyzing the published data, we found a large number of studies dealing only with the use of the full endoscopic technology (i.e. operations at the cervical level through percutaneous approaches, both anterior and posterior, providing only foraminotomy). ${ }^{15-17}$ It should be noted that in terms of technique, portal endoscopic methods at both the lumbar and cervical level are similar to microsurgical interventions, but they differ significantly from the latter in terms of the degree of trauma of soft tissues in accessing and in the quality of visualization.

\section{METHODS}

Our study included 25 patients with lateral disc herniations at level C5-C6 in 9 cases and C6-C7 in 16 cases, operated by endoscopic portal cervical discectomy. The control group consisted of 25 patients operated by microsurgical anterior cervical single-level discectomy with interbody fusion at levels C5-C6 and C6-C7. A more thorough analysis of these patients was described in previous papers. ${ }^{14,15}$
The patients of both groups were evaluated using the VAS score - radicular pain regression degree and timing, local cervical pain reduction based on the NDI (Neck Disability Index) - social adaptation of patients, and general recovery after surgery by the Odom criteria. The NDI enables the degree of social adaptation of the patient to be assessed based on the summation of points related to the ability to perform certain activities (walking, sleeping, reading, rest, etc.). The Odom criteria are used to characterize the effect of operation - from good to unsatisfactory. The evaluations using the NDI index and Odom test was carried out immediately before the patient's discharge. In addition, the estimated postoperative hospitalization time

Statistical analysis was performed using the Mann-Whitney test to determine the reliability of results.

This study was approved by the local ethics committee of the Neurology Research Center of (protocol no. 2/15 of 2/10/15).

\section{SURGICAL TECHNIQUE}

\section{Position on the operating table}

The patient is placed on the operating table in the prone position with the hands and arms alongside the body. The head is laid on a soft headrest or fixed in a Mayfield clamp. The neutral position of the cervical spine is established.

\section{Planning of the surgical incision}

We used X-ray in the lateral position for surgical incision planning. Usually it was placed $1-2 \mathrm{~cm}$ lateral to the midline, depending on the patient's composition.

\section{Operative access}

After the incision is made, the aponeurosis of the muscles is cut and under X-ray guidance, an endoscopic tube introduced in the projection of the desired level. (Figure 2)

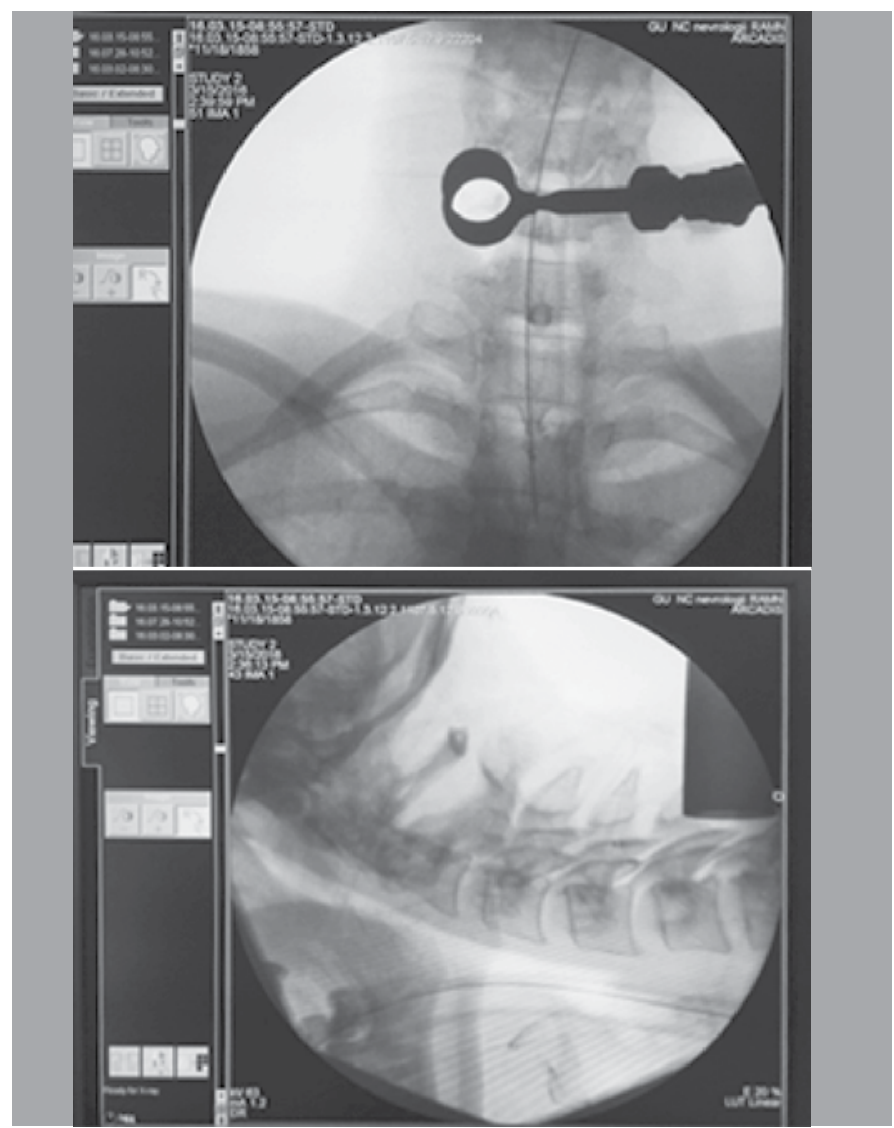

Figure 2. Fluoroscopic view of endoscopic port position 
The base of the lower articular process of lower vertebra is assumed as the optimal point for the installation of the port. After introducing the operating port, a slight resection of adjacent vertebral arches is performed, then the yellow ligament is exposed. If the port is properly installed, no significant resection of the intervertebral joint is required. However, various authors ${ }^{16-18}$ warn that the removal of $25 \%$ to $50 \%$ of the intervertebral joint can lead to segmental instability. After removing the soft tissues from the intralaminar gap, the yellow ligament is opened - preferably as medially as possible.

\section{Main stage of the operation}

Usually just after the yellow ligament opening, a dural sack can be perfectly visualized. When it is released from the fatty tissue, a nerve root funnel can be reached. Sometimes the funnel may be covered by the medial part of facet joint, necessitating a marginal resection. Along the funnel and a portion of the venous plexus can usually be visualized. (Figure $3 a$ ) Reckless movements in this position can lead to substantial blood loss, even requiring converting to microsurgery due to a lack of visualization. Nevertheless, thorough dissection of veins and nerve root funnel makes it possible to visualize the disc herniation and perform its removal. (Figure $3 \mathrm{~b}$ )

\section{Wound closure}

Layer wound suturing is performed. Particular attention is paid to restoring the integrity of muscle aponeuroses in the field of operational access.

In the early postoperative period, we advise the use of at least a mild cervical orthosis for 3 weeks to reduce axial load on the operated spinal-motor segment and discipline the patient in case of physical activity and what movements are not correct. and how to perform every-day activity correctly. That's a discipline. In case of russian people it's not sufficient to say when you can load your spine - you need to say that for example refrigerator movement is prohibited, barrel movement above 20 kilos is prohibited and soon.

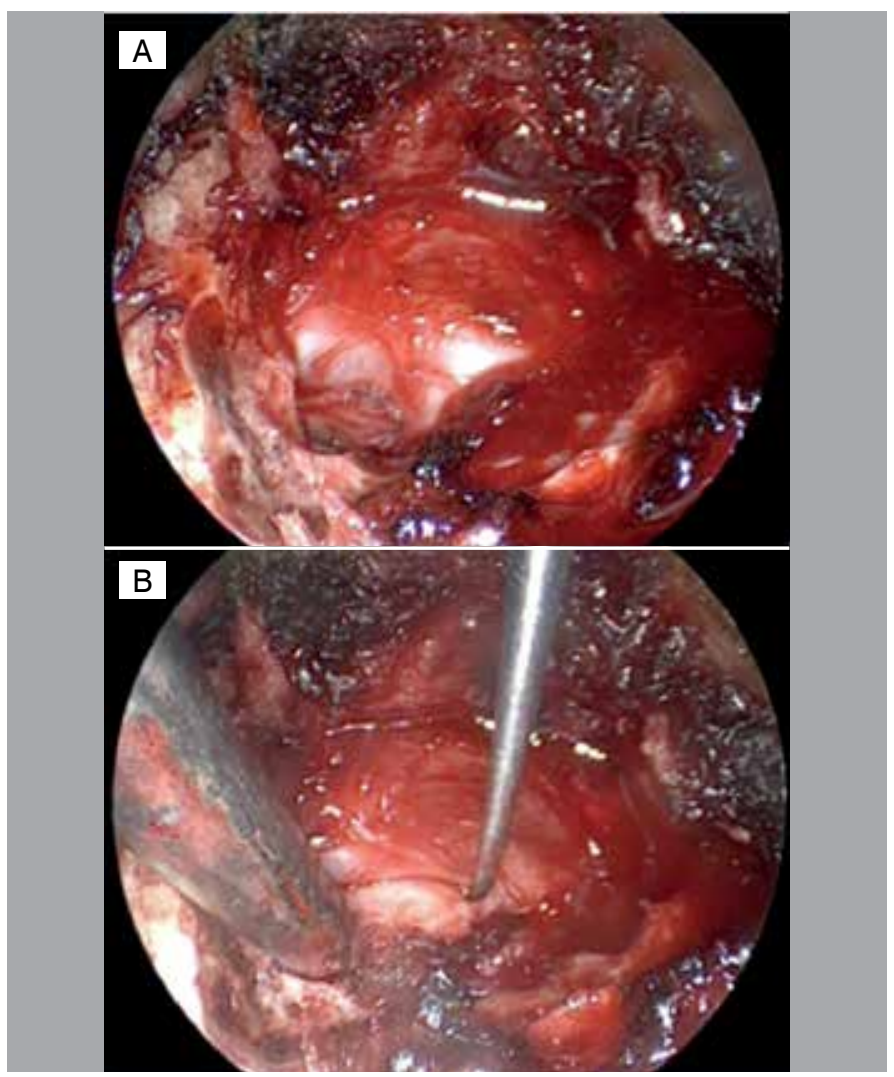

Figure 3. Main operation stage.

\section{RESULTS}

In both the study group and the control groups, there was no increase in the neurological deficit. In 2 (8\%) patients in the group with endoscopic disc removal, transient numbness occurred in the zone of innervated dermatome, which had regressed completely by the time of discharge from hospital. In the preoperative period, the median intensity of the pain syndrome in the shoulder and forearm according to the Visual Analogue Scale (VAS) was $6(3 ; 8)$ in the group with posterior endoscopic discectomy and $6(4 ; 8)$ in the group with anterior microsurgical discectomy. After the operation, this indicator decreased to $1(0 ; 6)$ in the group with endoscopic posterior discectomy, and $2(1 ; 6)$ in the group with microsurgical anterior discectomy. In both groups, there was a significant decrease in pain syndrome $(p$ $=0.016$ and $p=0.034$, respectively). Before discharge from hospital, the level of pain syndrome in the shoulder and forearm in the two groups did not differ significantly $(p>0.05)$. When assessing the pain syndrome in the neck, the comparability of the two groups in the preoperative period $(p>0.05)$ and a significant reduction in the level of pain in the postoperative period ( $p=0.024$ in the study group and $p=0.034$ in the control group) were noted. (Table 1 )

All patients of the study group immediately after the operation noted complete or near complete regression of the pain.

A significant improvement in the scores in patients who underwent endoscopic surgery was noted. The patients of both groups were subjectively satisfied with the result. With regard to the Odom test, there was also an advantage for the patients of the study group in terms of the number of excellent to good results. (Table 2)

Significant differences in postoperative hospitalization times were noted: in the study group, the term was 3 [2; 5] days, and in the control group, $5[4 ; 6]$ days. In the study group, 1 (4\%) patient noted the repeated appearance of radicular pain syndrome one week after the operation. The MRI data of this patient before and after the operation are shown in Figures 4 and 5.

Control MRI showed that the disc herniation is completely removed and the pain syndrome is not associated with its relapse. After receiving antineuritic therapy for 2 weeks, the pain syndrome completely regressed.

Table 1. Intensity of local pain in the neck and forearm according to the VAS.

\begin{tabular}{c|c}
$\begin{array}{c}\text { Group of patients } \\
\text { who underwent the } \\
\text { endoscopic procedure } \\
\text { (N=25) }\end{array}$ & $\begin{array}{c}\text { Group of patients who } \\
\text { underwent the anterior } \\
\text { microsurgical procedure } \\
(N=25)\end{array}$ \\
\hline
\end{tabular}

Pain in forearm and shoulder

\begin{tabular}{c|c|c}
\hline Score before operation & $6[3 ; 8]$ & $6[4 ; 8]$ \\
\hline Score before discharge & $1[0 ; 4]$ & $2[1 ; 6]$ \\
\hline Mann-Whitney Test, & 0.016 & 0.034 \\
\hline \multicolumn{3}{|c|}{ Local neck pain } \\
\hline Score before operation & $5[2 ; 6]$ & $6[3 ; 7]$ \\
\hline Score before discharge & $1[0 ; 3]$ & $3[1 ; 5]$ \\
\hline Mann-Whitney Test, & 0.024 & 0.034 \\
\hline
\end{tabular}

Table 2. Outcome according to the NDI and Odom criteria

\begin{tabular}{c|c|c}
\hline & $\begin{array}{c}\text { Group of patients } \\
\text { who underwent the } \\
\text { endoscopic procedure } \\
\text { (N= 25) }\end{array}$ & $\begin{array}{c}\text { Group of patients who } \\
\text { underwent the anterior } \\
\text { microsurgical procedure } \\
\text { (N= 25) }\end{array}$ \\
\hline \multicolumn{2}{|c}{ NDI index median and interval scores } \\
\hline Score before operation & $24[8 ; 32]$ & $23[6 ; 39]$ \\
\hline Score before discharge & $13[5 ; 25]$ & $13[5 ; 19]$ \\
\hline Mann-Whitney Test, & 0.056 & 0.026 \\
\hline \multicolumn{2}{c}{ Odom criterion (number of patients) } \\
\hline Excellent to good & 21 & 17 \\
\hline Average to bad & 4 & 8 \\
\hline
\end{tabular}




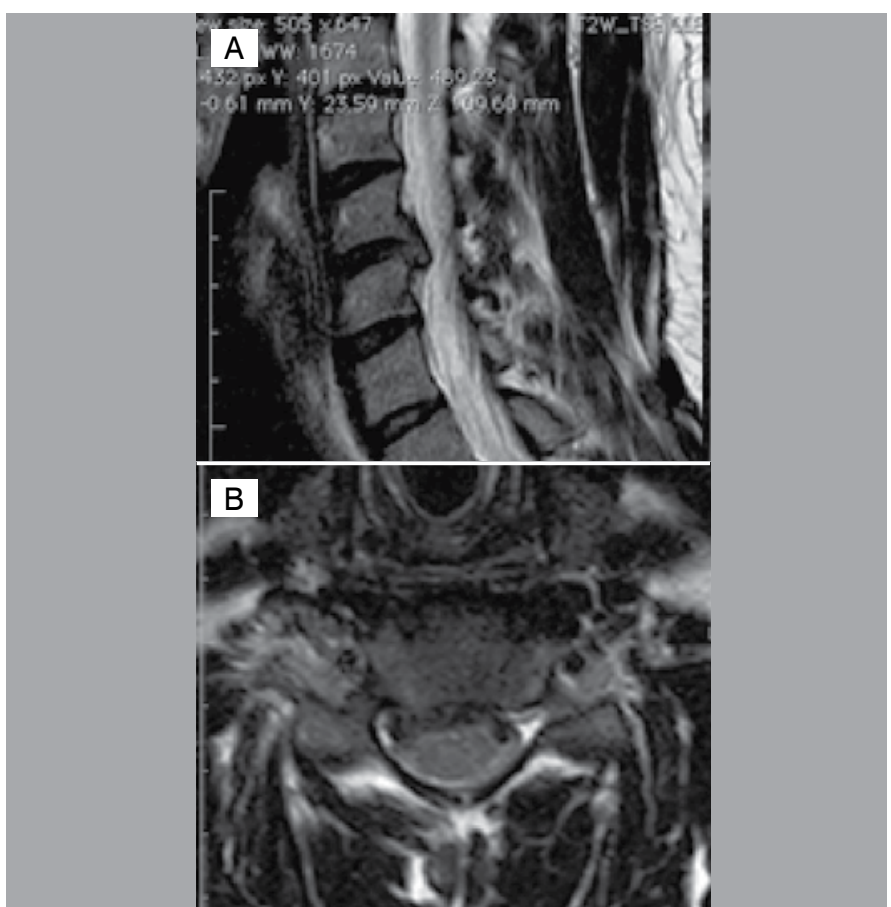

Figure 4. MRI before operation.
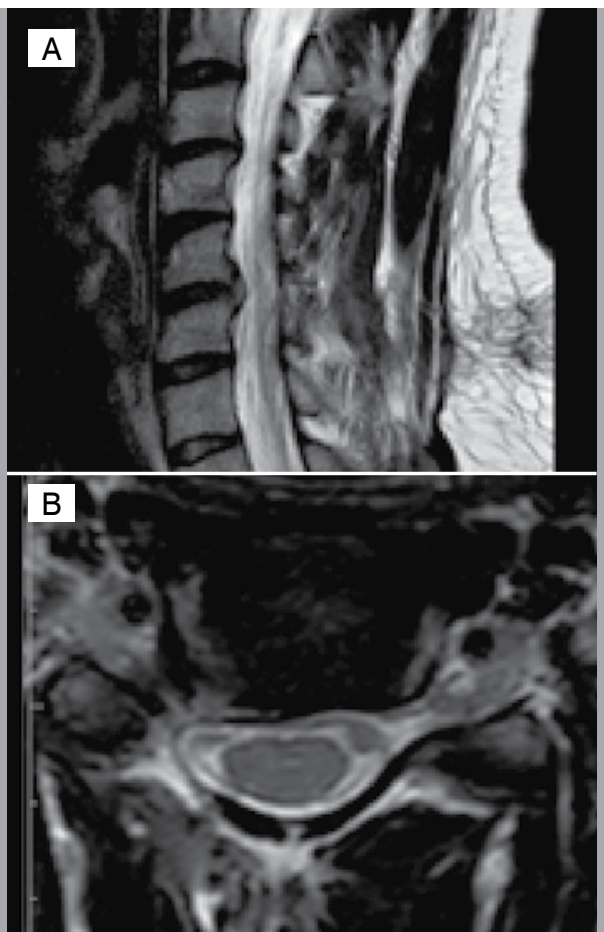

Figure 5. MRI after operation.

\section{DISCUSSION}

Although surgery for the treatment of compression syndromes represented by neurological and vascular disorders has existed for a long time,$^{15}$ there is still controversy surrounding the best approach. The main one is which approach option to choose to access the site of decompression - anterior or posterior. Both access routes enable the task to be fully carried out, the choice of access being determined by the site of the compressing factor, which is proven for single-level interventions.

According to $\mathrm{H}$. Jho, expressed in a private conversation, posterior cervical foraminotomy has limitations in anterior compression with osteophyte, posterior compression with a univertebral joint and with a pronounced cicatricial process. Dealing with clinical syndrome of cervical radiculopathy requires an even more thorough examination of the patient, as it is often not accompanied by unambiguous radiographic evidence of the cause of compression, and almost never involves pathognomonic changes in the neurovascular structures. As the main criterion for deciding on the level of radiculopathy, greater reliability for detecting muscle atrophies in the corresponding muscles has been proven. Modern neuroimaging methods enable us to determine the nature of the compressing factor: "soft" (herniated intervertebral disc) or "hard" (osteophyte or bone spur) - this is decisive in the choice of surgical access. In the presence of a lateral soft disc, a posterior endoscopic portal removal is shown, whereas an osteophyte in this zone can be more radically eliminated by a ventral approach. The nature of the compressing factor in cervical radiculopathy syndrome should also be considered in relation to neurological symptoms. In the presence of an osteophyte, the severity of radicular symptoms (especially pain) is significantly lower than in the formation of a "soft" hernia.

The ineffectiveness of surgical treatment of patients with radiculopathy, according to our data, is due mainly to the underestimation of neurological symptoms and the interpretation of neuroimaging data. In particular, the paramedian location of the herniated intervertebral disc is often accompanied by radicular symptoms in the opposite arm. Ignorance of this fact can cause inadequate choice of the side of surgical access and, accordingly, lack of clinical effectiveness of the operation.

A significant factor in selecting the surgical access is confirmed deformity of the spine and identified segmental instability. Kyphosis of the cervical region, associated with degenerative process in the vertebrae, always involves the use of ventral access with appropriate stabilizing measures.

Based on the data obtained and the results of the operations performed, we developed an algorithm for selecting surgical access in the formation of spinal cord compression at the cervical level. (Figure 6)

The use of endoscopic microdiscectomy in the treatment of herniated intervertebral discs of the cervical spine has rather high efficiency and allows clinical results to be achieved with significantly lower operational injury. The technical features and proposed recommendations revealed by us will contribute to the wider introduction of this promising low-traumatic method in neurosurgical practice.

\section{CONCLUSION}

Our studies demonstrate the safety and effectiveness of the posterior portal endoscopic discectomy method. This type of intervention, with fairly clear ideas about the anatomical features of the compressing factor, is more effective than other operations in terms of speed of rehabilitation and social adaptation of patients, and also shortens the postoperative hospital times.

Based on our results, we propose and approve indications and contraindications for cervical portal endoscopic discectomy.

This operation is indicated if:

- the clinical data from radiculopathy corresponds to the side and the level of lesion detected during MRI/CT examination;

- CT/MRI data confirm the compliance of the "soft" compression of the spine located in the lateral third of the diameter of the vertebral canal, the clinical symptoms of the disease;

- There is no effect of conservative treatment, conducted over 3 weeks.

The operation is contraindicated if:

- there are signs of segmental instability;

- there is a kyphotic deformation of the spine at the level of disc herniation.

All authors declare no potential conflict of interest related to this article. 


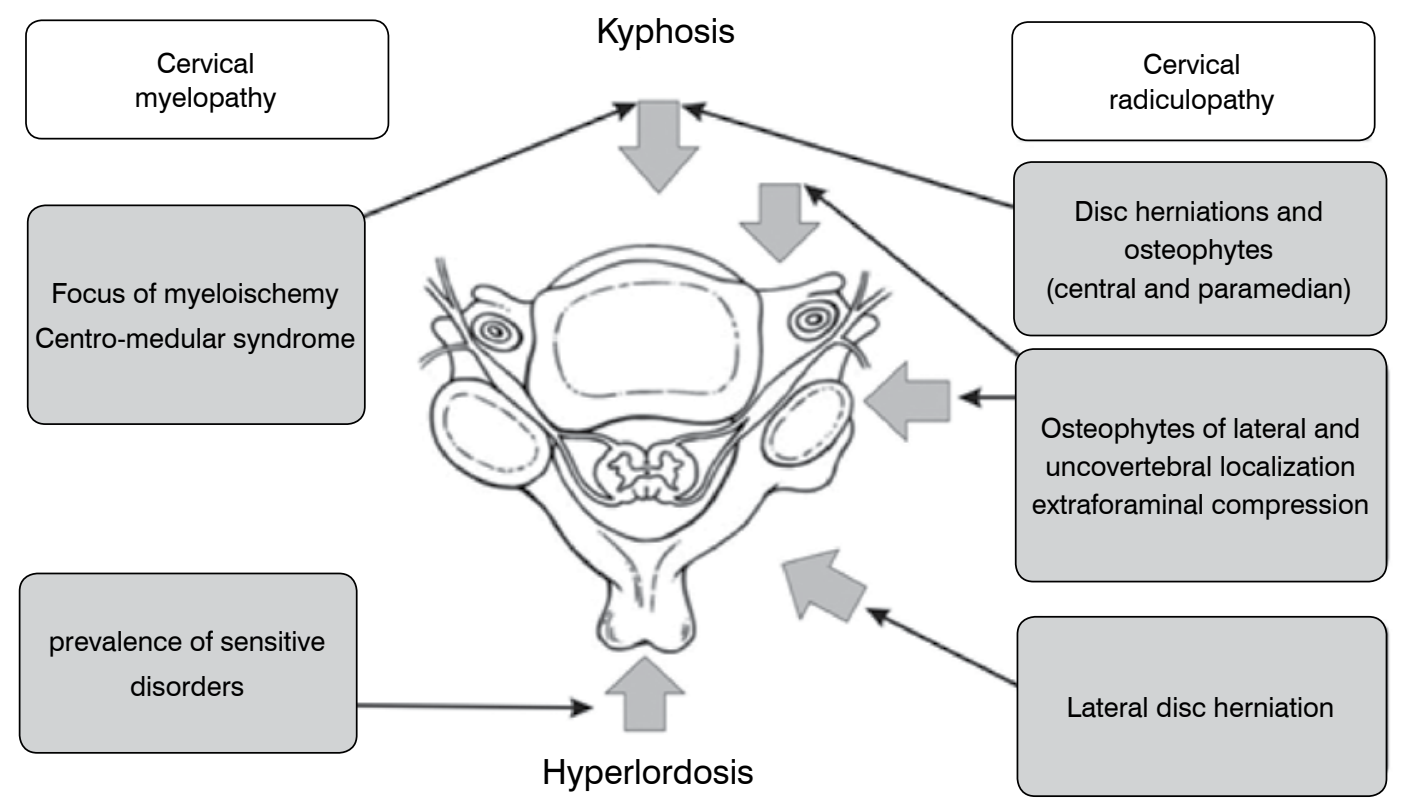

acess direction

Figure 6. Algorithm of preferred surgical access to the cervical spine.

CONTRIBUTION OF THE AUTHORS: AG (0000-0003-3451-5750)^, SA (0000-0003-4809-4117)* and AV (0000-0002-8006-1334)* actively and equally performed listed below operations and actively contributed to this article. AK (0000-0001- 7681-3073)* and MD (0000-0002-7839-309X)* assisted in surgery, followed up the patients and gathered clinical data. EP (0000-0001-9208-2987)* and DP (0000-0001-9588-7721)* evaluated the data from the statistical analysis. VT (0000-0003-4881-4241)* performed the literature search and review of the manuscript, and contributed to the intellectual concept of the study. *ORCID (Open Researcher and Contributor ID).

\section{REFERENCES}

1. Lawrence JC. Disc degeneration: its frequency and relationship to symptoms. Ann Rheum Dis. 1969;28(2):121-38.

2. Decoulx P, Houcke E, Razemon JP, Lemerle P. Anatomie pathologique de la hernie discale. Presse Med. 1958;66(40):899-902.

3. Bland J.H. Disorders of the Cervical Spine: Diagnosis \& medical management. 2nd ed. Philadelphia: WB Saunders Company, 1994

4. Popelyansky Ya.Yu. Bolezni perifericheskoy nervnoy sistemi: Guidelines. Moscow: Medicine, 1989.

5. Knightly JJ, Greene KA, Marciano FF, Ronderos JF, Sonntag VK. Locked facets and disc herniation. J .Neurosurg. 1994;80(5):952-3.

6. Wilmink JT, Hofman PAM. T2-weighted 3D FSE MR myelography in the cervical spine: comparison of 2 techniques. Neuroradiology. 1995:37(Suppl. S56): 56.

7. Smith GW, Robinson RA. The treatment of certain cervical-spine disorders by anterior removal of the intervertebral disc and interbody fusion. J.Bone Joint Surg Am. 1958;40-A(3):607-24.

8. Szpalski M, Gunzburg R (Eds). The Degenerative Cervical Spine. Philadelphia: Lippincott Williams \& Wilkins; 2001.

9. Shen FH, Samartzis D, Khanna N, Goldberg EJ, An H. Comparison of clinical and radiographic outcome in instrumented anterior cervical discectomy and fusion with or without direct uncovertebral joint decompression. Spine J. 2004:4(6):629-35.

10. Spurling RG, Segerberg LH. Lateral intervertebral disk lesions in the lower cervical region. J Am Med Assoc. 1953;151(5):354-9.
11. Shevelev IN, Goushcha AO. Degenerative and dystrophic diseases. Moscow: Publishing house of Vladimir Levin; 2010.

12. Guscha AO, Arestov SO. Endoscopic Spinal Surgery. Moscow: GEOTAR-Media; 2010.

13. Yang JS, Chu L, Chen L, Chen F, Ke ZY, Deng ZL. Anterior or posterior approach of fullendoscopic cervical discectomy for cervical intervertebral disc herniation? A comparative cohort study. Spine (Phila Pa 1976). 2014;39(21):1743-50.

14. Li XC, Zhong CF, Deng GB, Liang RW, Huang CM. Full-Endoscopic Procedures Versus Traditional Discectomy Surgery for Discectomy: A Systematic Review and Meta-analysis of Current Global Clinical Trials. Pain Physician. 2016;19(3):103-18.

15. Nowinski GP, Visarius H, Nolte LP, Herkowitz HN. A biomechanical comparison of cervical laminoplasty and cervical laminectomy with progressive facetectomy. Spine (Phila Pa 1976). 1993;18(14):1995-2004

16. Raynor RB, Pugh J, Shapiro I. Cervical facetectomy and its effect on spine strength. J Neurosurg. 1995;63(2):278-82.

17. ZdeblickTA, Ducker TB. The use of freeze-dried allograft bone for anterior cervical fusions. Spine (Phila Pa 1976). 1991;16(7):726-9.

18. Goushcha AO, Arestov SO. Torakoscopicheskaya chirurgiya v lecheniyi novoobrazovaniy pozvonochnika i paraspinal'nih opuholey. Russian traumotology and orthopedy. 2010;2(56):129-31. 